\title{
The dynamics of appraisal: a review of 20 years of research using the Fortitude Questionnaire
}

\author{
Tyrone Brian Pretorius \\ and Anita Padmanabhanunni ${ }^{\text {iD }}$
}

\begin{abstract}
Fortitude refers to the psychological strength to manage adversity and stay well. It is derived from adaptive cognitive appraisals of self, family, and social supports and has consistently been identified as a protective factor in psychological well-being. This study undertakes a scoping review of empirical research on the Fortitude Questionnaire, which was developed to assess levels of fortitude. The aims of the study were to categorize and catalogue studies that have used the Fortitude Questionnaire, identify the variables that have been linked to the scale, and determine the extent to which prior research has replicated the Fortitude Questionnaire's psychometric properties. Arksey and O'Malley's five-stage framework for scoping reviews was followed to review studies published between January 1999 and March 2020. A total of 51 studies met the inclusion criteria. The scoping review found that the Fortitude Questionnaire has been used in different contexts and among various sample groups across the lifespan, including vulnerable and high-risk populations. The scale has demonstrated sound reliability and studies have confirmed its factor structure. The scale has also been used as an independent, dependent, and intervening variable. Fortitude has been linked to positive and negative indicators of well-being, and intervention studies have indicated that fortitude is amenable to change. The findings of this scoping review provide a foundation for the development of appraisal restructuring programmes and interventions.
\end{abstract}

\section{Keywords}

Fortitude, Fortitude Questionnaire, psychometric properties, review, well-being

Adverse life events evoke psychological distress and emotional upheaval for some individuals and lead to positive adaptation and effective coping for others. Cognitive appraisals of stressors have been identified as a central mechanism underling this differential vulnerability to adversity

University of the Western Cape, South Africa

Corresponding author:

Tyrone Brian Pretorius, University of the Western Cape, Robert Sobukwe Rd., Bellville, Cape Town 7535, South Africa. Email: tpretorius@uwc.ac.za 
(Chishima et al., 2018; Gomes et al., 2017; Yeung et al., 2016). This mechanism includes primary appraisal, which represents an immediate evaluation of a stressor in relation to well-being, and secondary appraisal, which refers to an evaluation of the extent to which they can activate resources for coping (Lazarus \& Folkman, 1984). Existing research on adversity has largely focused on the influences of negative primary and secondary appraisals on psychological outcomes (Cao et al., 2016; Gomes et al., 2017). Comparatively less research has investigated the role of positive appraisals.

Drawing on the seminal theory of salutogenesis (Antonovsky, 1979), T. B. Pretorius (1998) proposed the construct of fortitude, which is defined as the psychological strength to cope with life stressors. According to T. B. Pretorius (1998), fortitude is derived from positive (fortigenic) appraisals of one's self, family, and external sources of support. These appraisals are presumed to activate the individual's salutogenic potential and facilitate coping by influencing the way in which adverse events are appraised. Support for this notion has come from studies on vulnerable populations (De Villiers \& Van den Berg, 2012; Padmanabhanunni, 2020; T. B. Pretorius et al., 2016).

Based on the theory of fortitude, T. B. Pretorius (1998) developed the Fortitude Questionnaire (FORQ), which assesses three dimensions of fortigenic appraisals: self-appraisal, which includes a global positive evaluation of oneself and specific positive appraisals of one's competence and capacities; family which includes an evaluation of the family environment and family as cohesive, responsive, and accessible in times of stress; and support appraisal, which includes an evaluation of the availability, accessibility, and value of support from others, such as friends and peers.

It has been suggested (T. B. Pretorius et al., 2016) that fortitude bears similarity to the construct of resilience. However, fortitude is based on a theory of appraisal, whereas resilience is typically conceptualized as the ability to maintain stable psychological functioning when confronted with a stressor. A variety of measures have been developed to assess resilience but these scales are not comparable with the FORQ because they assess different constructs and are grounded in a different paradigm.

The FORQ has been extensively used since its development. Hence, the goal of this study is to conduct a scoping review on the use of the FORQ in research over the past 20 years. The aims of the study are threefold and entail (1) categorizing and cataloguing studies that have used the FORQ, (2) identifying the variables that have been linked to the scale, and (3) determining the extent to which prior research has replicated the FORQ's psychometric properties.

\section{Method}

A scoping review was undertaken during December 2019 and March 2020 to map the literature on fortitude since the development and validation of the FORQ (T. B. Pretorius, 1998). Scoping reviews represent a means of summarizing and synthesizing the knowledge in a particular area and are typically used to assess the range and nature of research on a specific topic (Arksey \& O'Malley, 2005). The methodology for the scoping review was guided by the frameworks of Arksey and O'Malley (2005) and Levac et al. (2010) and included the following phases: (1) generating the research question, (2) identifying and selecting relevant studies, (3) charting the data, and (5) collating, summarizing, and synthesizing the results.

\section{Research question, data sources, and search terms}

This scoping review was guided by the following questions: 'What are the types and characteristics of studies that have used the FORQ?' and 'Were studies that have used the FORQ able to replicate its psychometric properties?' The initial search was implemented in December 2019 and was conducted using Google Scholar, PubMed, Academic Search Premier, Sabinet African Journals, EBSCO Open 
Access Medical and Health Collection, Academic Search Complete, and UKWAZI (the local library search engine). The databases were selected to be comprehensive and to cover a broad range of fields of study. Search terms included 'fortitude', 'fortitude questionnaire', 'fortitude scale', and 'FORQ'.

\section{Screening process and eligibility criteria}

A two-stage screening process was used to assess the suitability of studies identified in the search. First, studies were eligible for inclusion if they used the FORQ and were published in either English or Afrikaans in the period 1999-2020 (January 1999-March 2020). Second, the title and abstract of identified studies were independently screened by each of the authors separately to ensure that these studies adhered to the inclusion criteria. All studies appraised as relevant were procured for full-text review and were reviewed by each author separately to promote rigour. The reference list of the selected studies was also mined to identify suitable studies.

\section{Data extraction and synthesis}

All included articles were captured and charted on an Excel spreadsheet (Microsoft Corporation, 2016). The characteristics of each selected study were extracted by the authors. This included type of study design, year of publication, characteristics of study population, findings of the study, and countries where the study was conducted. The methodological quality of the selected studies was not appraised.

\section{Results}

The initial search terms yielded 2631 results across a range of disciplines. A secondary search excluded the term 'fortitude', and this excluded 2451 of the original results. Duplicates across databases $(n=104)$, dissertations published as journal articles $(n=12)$, and studies that only included the FORQ as a reference $(n=12)$ were also removed. One study only used the individual items of the FORQ and was also excluded. In all, 51 studies met the inclusion criteria (see Figure 1).

The 51 studies are summarized in Table 1.

\section{Location and sample}

The FORQ has been used primarily in South Africa; however, it has also been used by researchers in Canada (Beattie et al., 2016), Indonesia (Yuwanto \& Atmadji, 2017), Nigeria (Adejuwon et al., 2015), and the United Arab Emirates (Hameed et al., 2016). The FORQ has been translated into Afrikaans (e.g., Bouma, 2000), Setswana (e.g., Khumalo et al., 2011), and Indonesian (Yuwanto \& Atmadji, 2017).

The FORQ has been used among sample groups across the lifespan, including children (e.g., De Villiers \& Van den Berg, 2012), adolescents (e.g., I. Pienaar, 2002), students (e.g., Hamid \& Singaram, 2016), and various adult samples, including nurses (Heyns et al., 2003), health club members (Edwards, 2003a), lay counsellors (Padmanabhanunni, 2020), police officers (Taylor, 2002), and entrepreneurs (Venter, 2004). It has also been used in research with vulnerable and under-researched populations such as learners with learning disabilities (Bouma, 2000), parents of handicapped children (Constandius, 2003), persons with head injuries (Helmand, 2001), students with physical disability (Hundermark, 2004), caregivers of spouses with Alzheimer's disease (J. C. Potgieter \& Heyns, 2006; C. Pretorius et al., 2009), women with the metabolic syndrome (Botha et al., 2007), and children with a life-threatening illness (Talbot, 2012). 


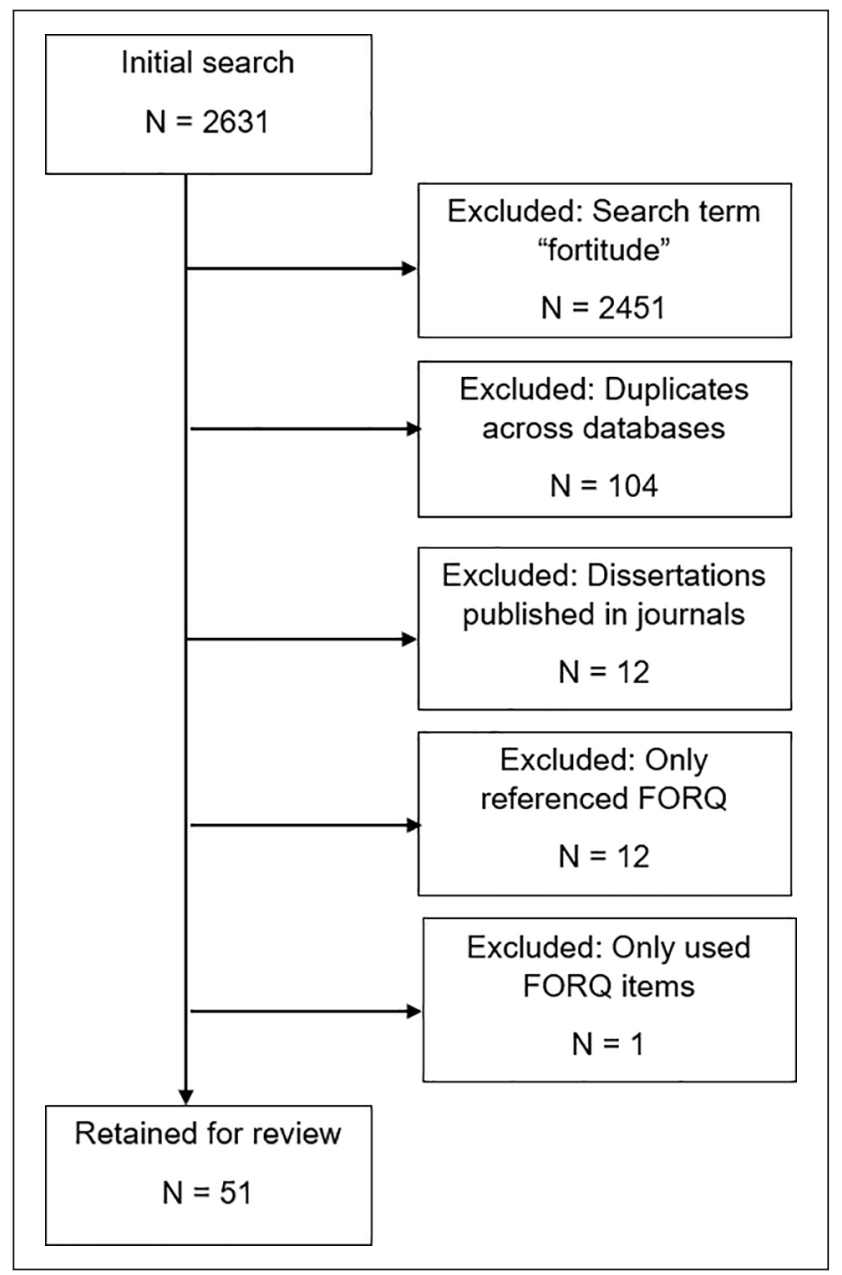

Figure I. Literature screening procedure.

\section{Research designs}

Most of the studies used the FORQ in a cross-sectional design, while some studies used it as an outcome measure to test the effectiveness of an intervention in quasi-experimental designs (e.g., Van Schalkwyk \& Wissing, 2013). Several triangulation studies used both qualitative and quantitative data (e.g., J. C. Potgieter, 2002; F. Potgieter, 2004), and one qualitative study explored the dimensions of fortitude (Hundermark, 2004).

\section{Psychometric properties of the FORQ}

The majority of studies reported favourable indices of internal consistency (Cronbach's alpha), ranging from .63 to .91 . Some exceptions were related to the self-appraisal subscale (see Laureano et al., 2014; Talbot, 2012; Wissing et al., 2008). The pattern of reliabilities for the FORQ and the subscales were similar across the majority of studies in that the total FORQ scale was the most 


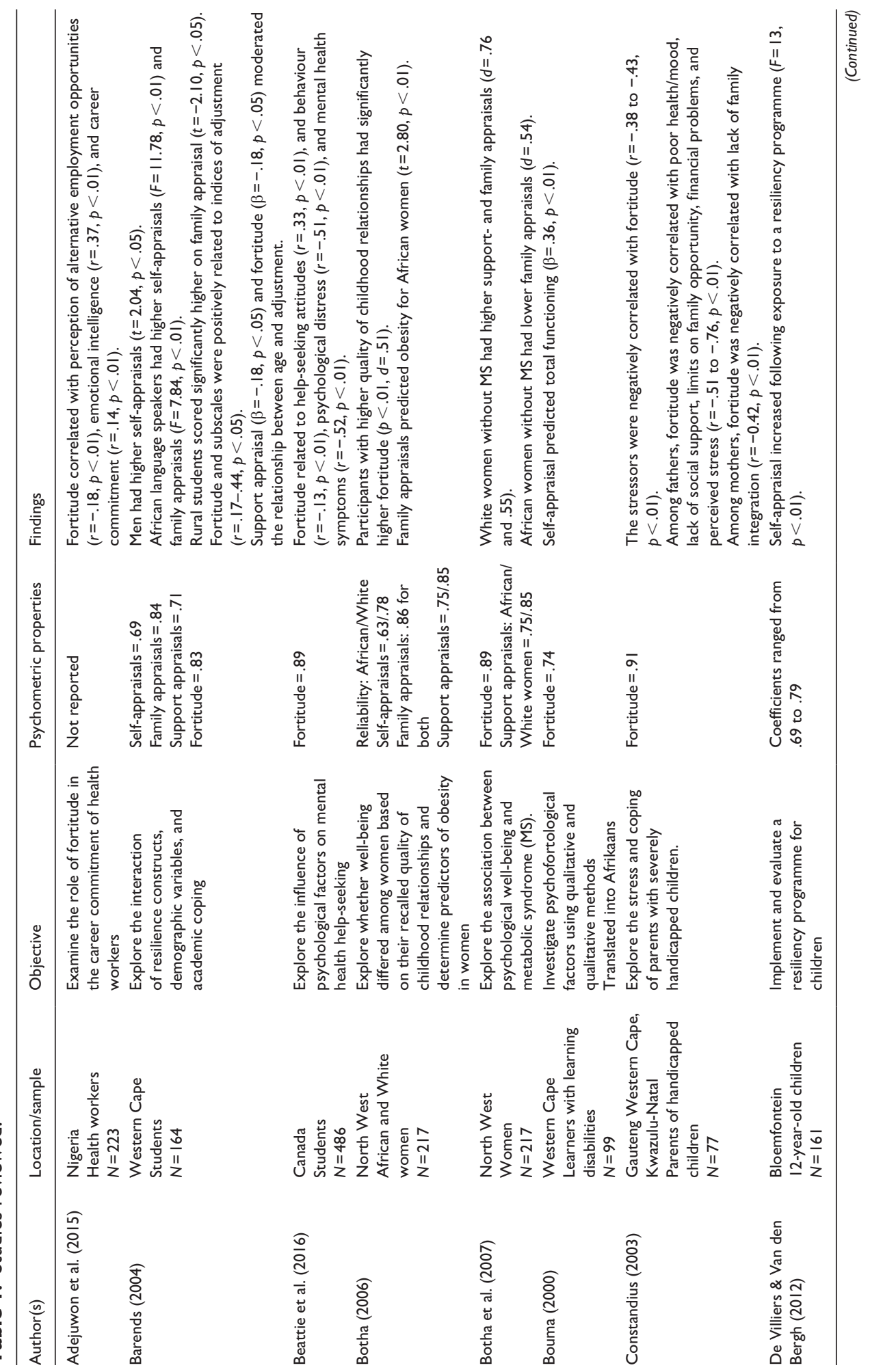




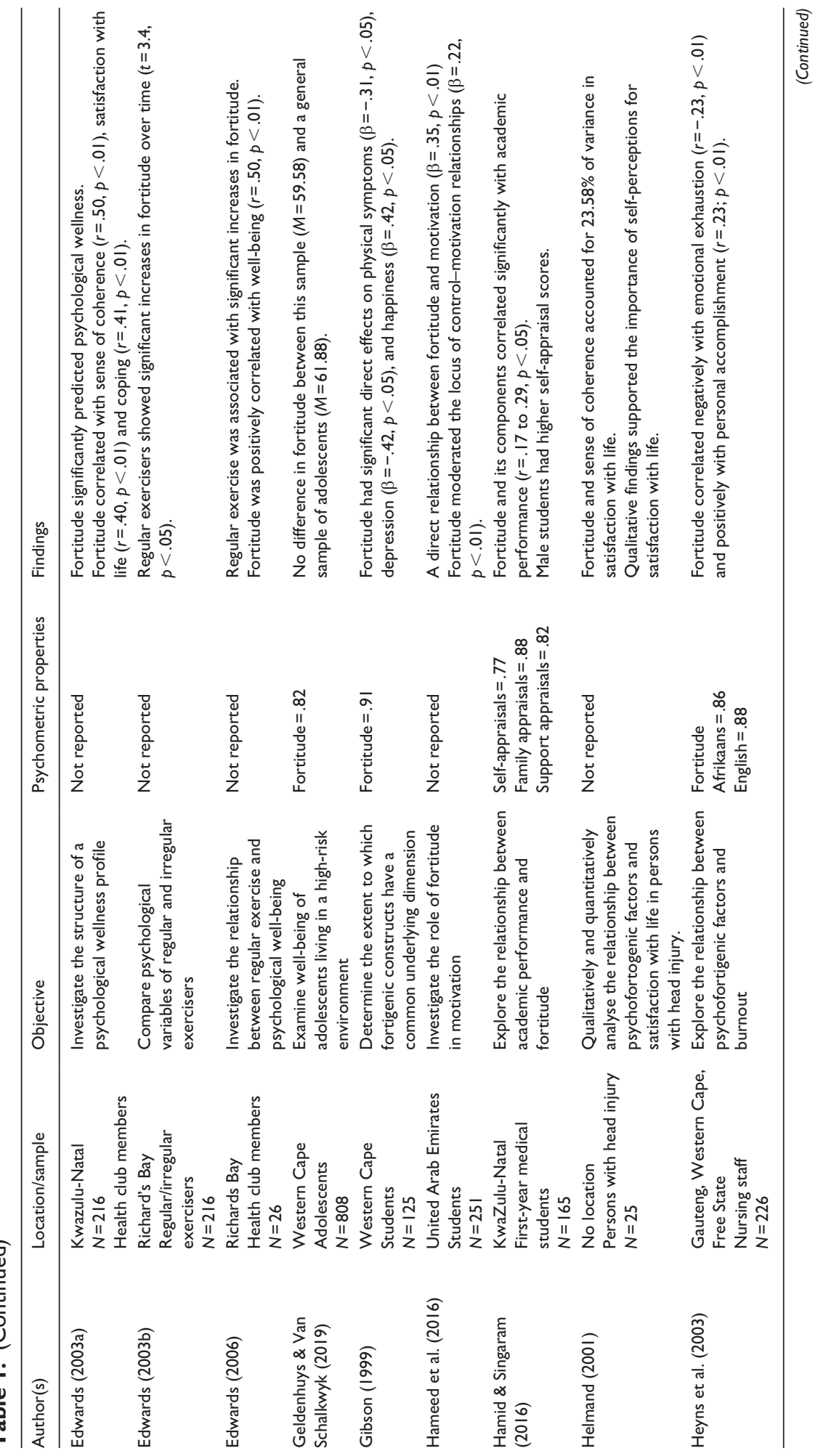




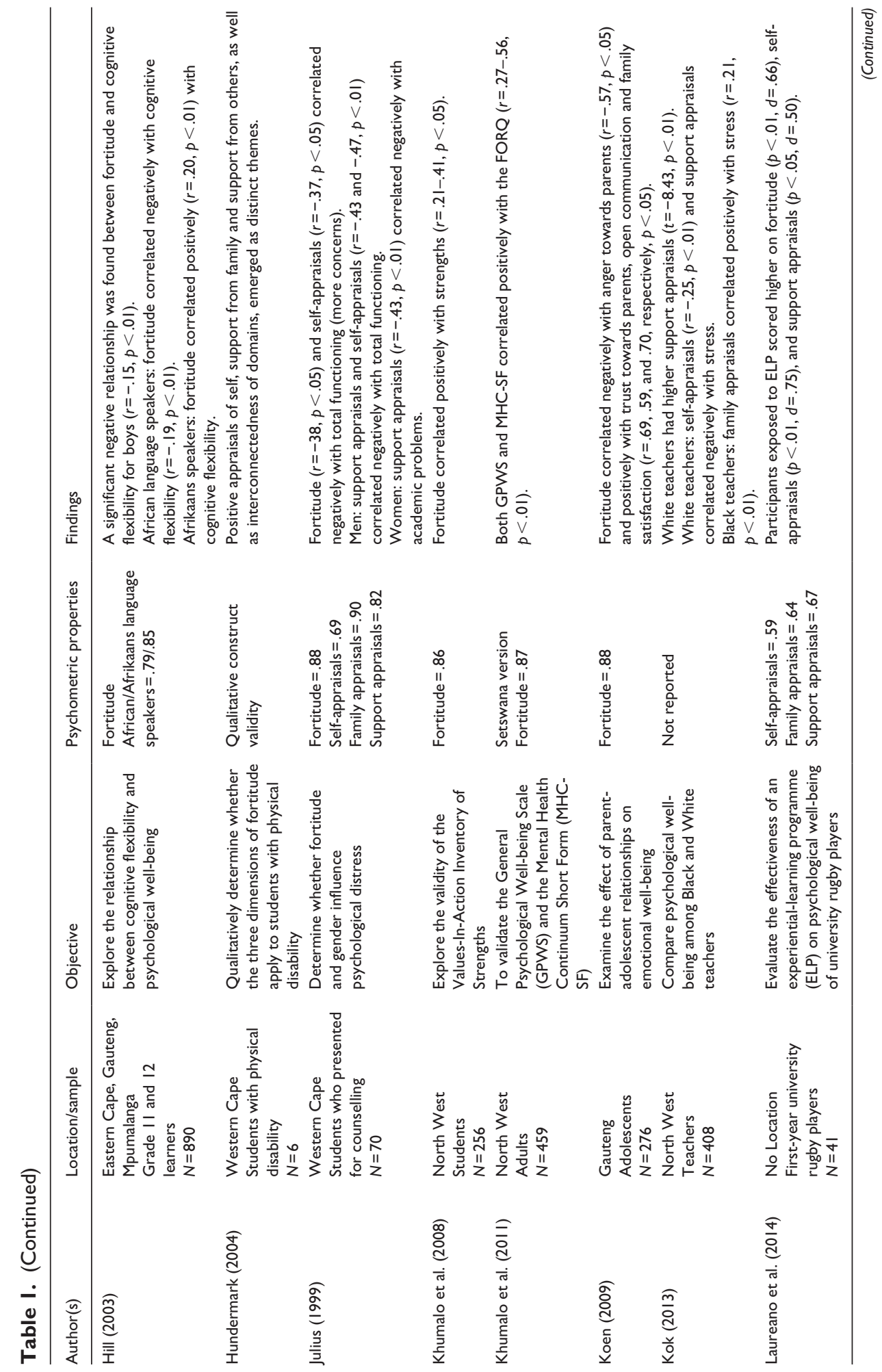




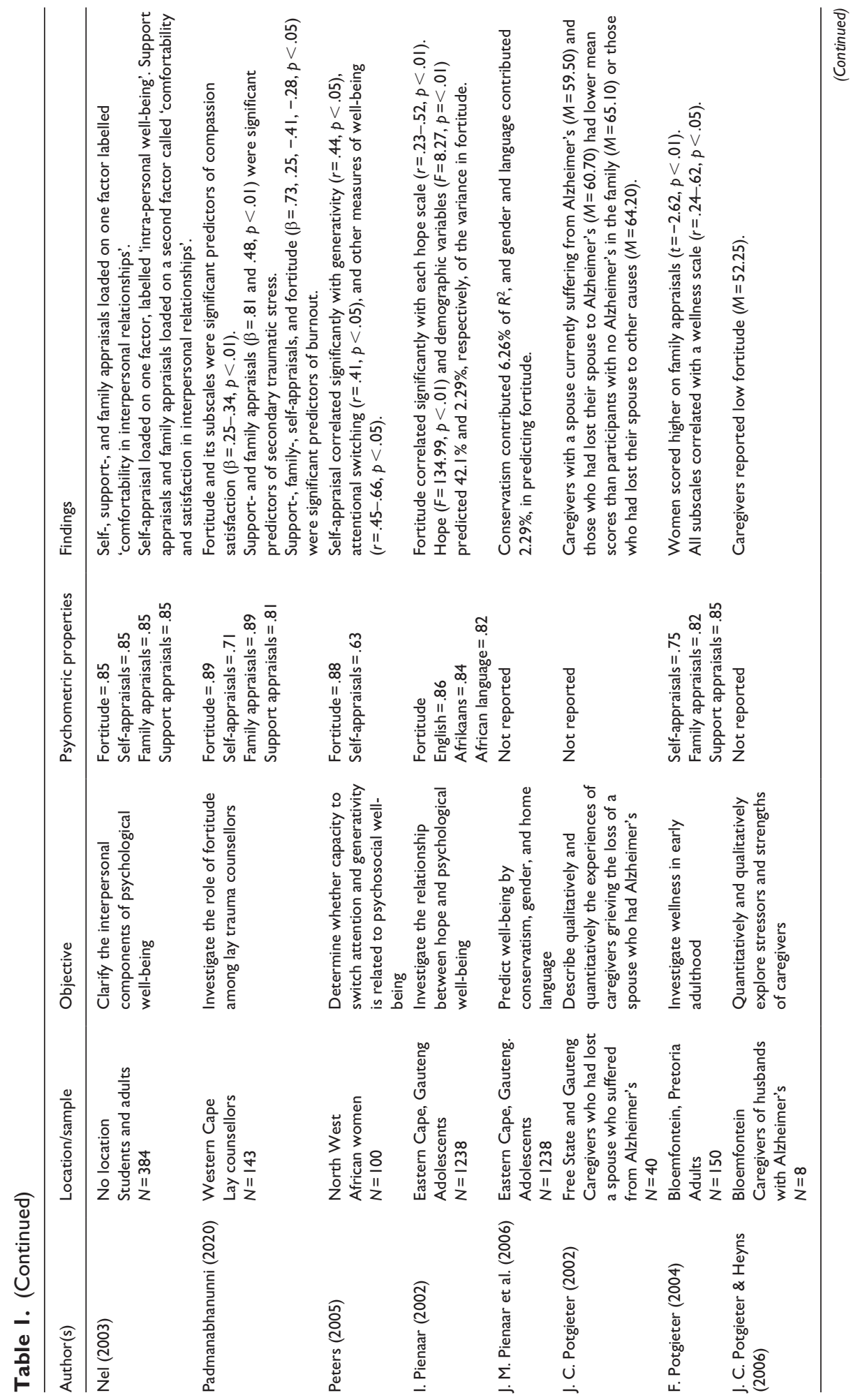




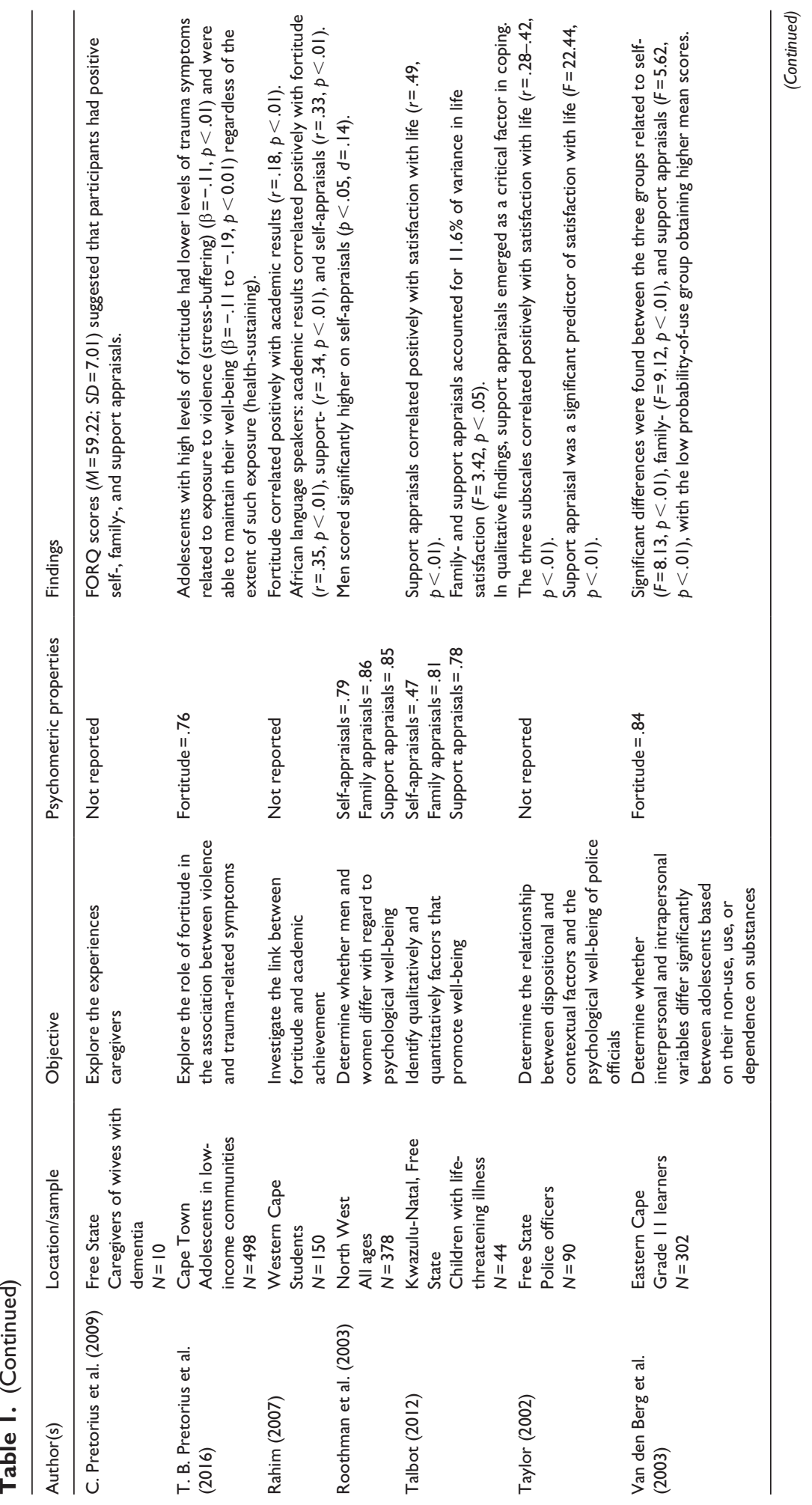




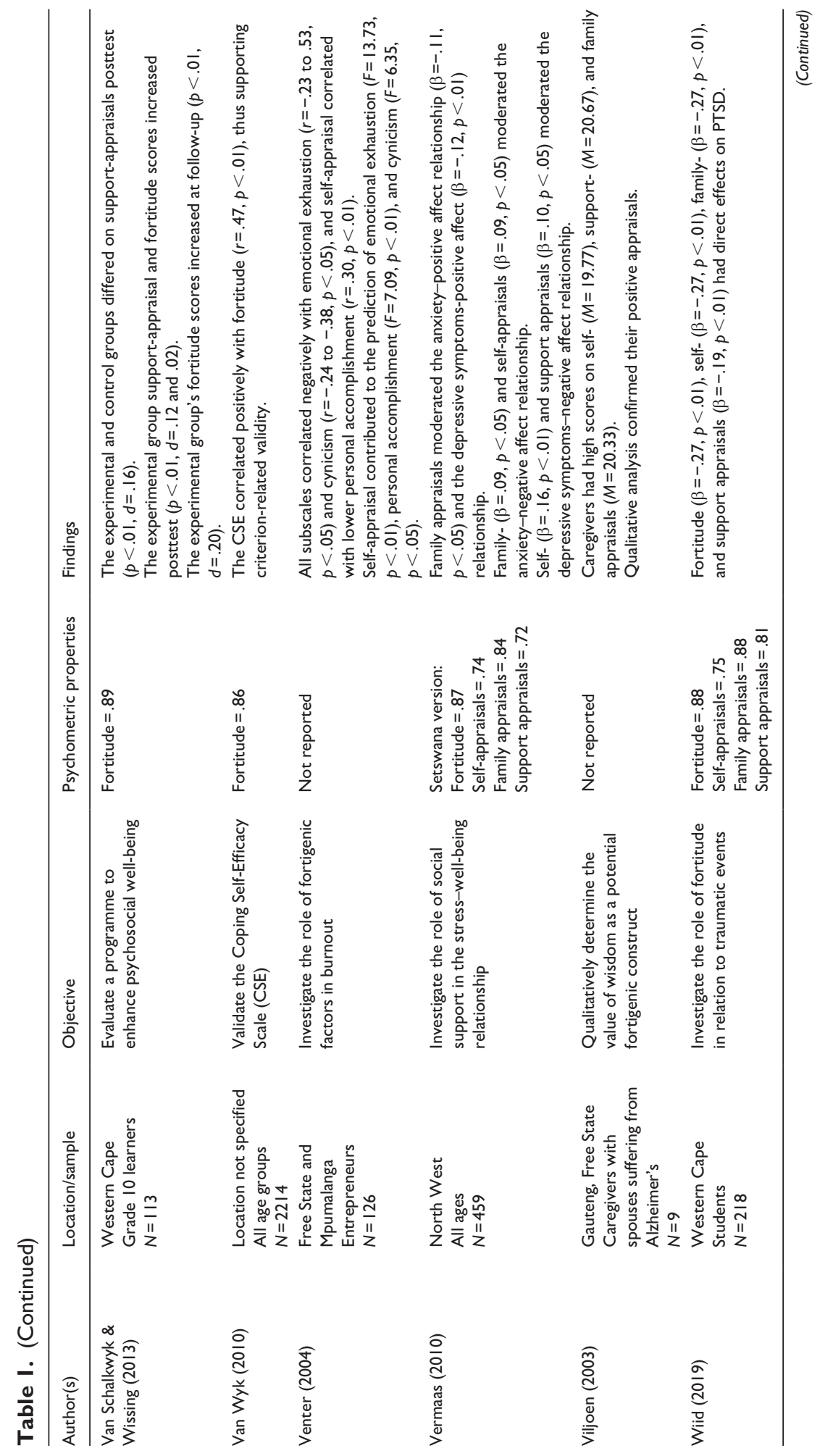




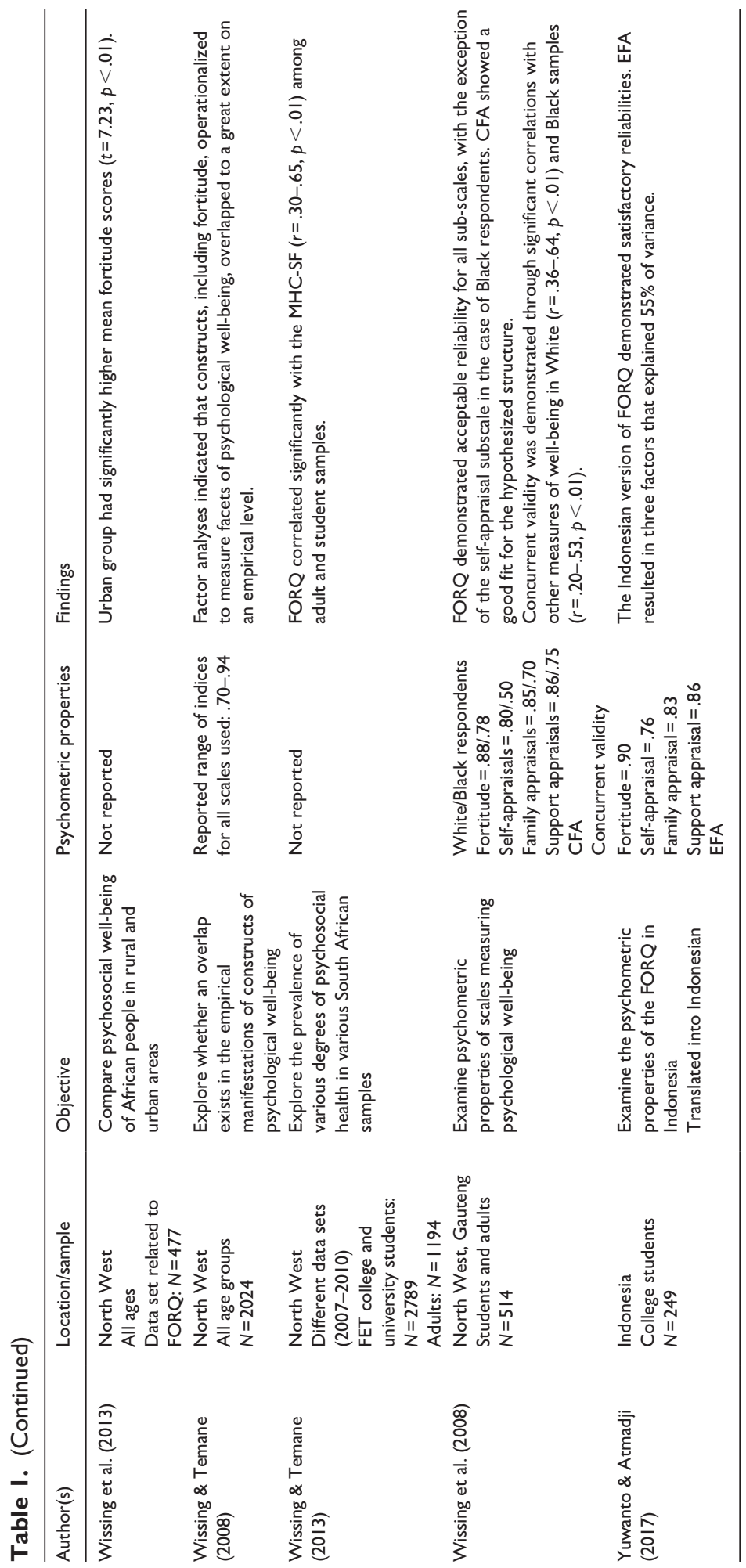


reliable and the self-appraisal subscale was the least reliable. Even in studies in which the selfappraisal subscale had low reliability, the total FORQ scale had high reliability (e.g., Wissing et al., 2008). The FORQ scale also demonstrated satisfactory reliability in Canadian $(\alpha=.89$; Beattie et al., 2016) and Indonesian ( $\alpha=.76-.90$; Yuwanto \& Atmadji, 2017) samples.

Researchers have used the structure of the FORQ in a variety of ways. For example, the FORQ has been used as a single scale (T. B. Pretorius et al., 2016), a total scale with subscales (Padmanabhanunni, 2020), only subscales (Laureano et al., 2014), and only selected subscales (Peters, 2005). Some studies (e.g., Botha et al., 2007) have used the family-appraisal subscale as a conceptual reflection of family support. Wissing et al. (2008) used exploratory (EFA) and confirmatory factor analyses (CFA) to examine the FORQ's structure. The CFA concluded that the three-factor structure best fit the data. However, the EFA resulted in a four-factor solution. In an Indonesian study, Yuwanto and Atmadji (2017) used an EFA to identify a three-factor solution.

The FORQ has a consistently significant relationship with other measures of well-being in a range of studies (e.g., Khumalo et al., 2011). Wissing et al. (2008) cited these concurrent relationships as evidence of the FORQ's validity. Further evidence of validity was found in a study that examined sources of strength among students with physical disabilities (Hundermark, 2004). Qualitative data analysis confirmed the dimensions of fortitude and the interconnectedness of the domains.

\section{Applications of the FORQ}

Demographic correlates of the FORQ. One study in which fortitude was a dependent variable (J. M. Pienaar et al., 2006) found that demographic variables predicted $2.29 \%$ of the variance in fortitude. Demographic variables, including gender (e.g., Roothman et al., 2003) and rural or urban setting (Wissing et al., 2013), have been linked to the FORQ. With respect to gender, studies have found that men (boys) reported higher self-appraisals.

Several studies have reported correlations between fortitude and outcome variables for respondents in different demographic categories. For example, gender differences have been observed in the relationships between fortitude and counselling concerns (Julius, 1999) and between fortitude and cognitive flexibility (Hill, 2003). Racial differences have been observed in the relationships between fortitude and obesity (Botha, 2006) and between fortitude and teacher stress (Kok, 2013).

FORQ as a criterion in validity studies. The FORQ has been used in validity studies of other instruments, including the Values-in-Action Inventory of Strengths (Khumalo et al., 2008), General Psychological Well-being Scale, the Mental Health Continuum Short Form (Khumalo et al., 2011), and the Coping Self-Efficacy Scale (Van Wyk, 2010). The FORQ correlated positively with each of these instruments, confirming criterion-related validity.

Intervention studies. The FORQ has been used as an outcome variable to assess the effect of interventions, including a resilience programme (De Villiers \& Van den Berg, 2012), an experientiallearning programme (Laureano et al., 2014), and a programme intended to enhance well-being (Van Schalkwyk \& Wissing, 2013). Participants exposed to these interventions reported higher fortitude, self-, and support appraisals.

Positive and negative psychological well-being. The majority of research has focused on the FORQ's link to well-being. Some studies have conceptualized it as part of psychological well-being (Botha, 2006; Nel, 2003), rather than as a variable that might impact well-being. 
Fortitude has been positively related to indices of positive well-being, including satisfaction with life (Edwards, 2003a) and happiness (Gibson, 1999). It has been negatively related to indices of negative well-being, such as psychological distress and mental health symptoms (Beattie et al., 2016), physical symptoms and depression (Gibson, 1999), emotional exhaustion (Venter, 2004), burnout (Padmanabhanunni, 2020), and trauma-related symptoms (Wiid, 2019).

Some studies have investigated the potential role of fortitude as a mediator or moderator. Fortitude has been found to moderate the relationship between age and academic adjustment (Barends, 2004), locus of control and motivation (Hameed et al., 2016), violence and trauma symptoms (T. B. Pretorius et al., 2016), and the anxiety-negative affect and depressive symptomsnegative affect relationships (Vermaas, 2010).

Other related variables. Fortitude has been linked to quality of childhood experiences (Botha, 2006), regular physical exercise (Edwards, 2006), parent-adolescent relationships (Koen, 2009), attentional switching and generativity (Peters, 2005), academic performance (Hamid \& Singaram, 2016; Rahim, 2007), and academic adjustment (Barends, 2004). It has also been found to differentiate between adolescents with a low probability of substance use, those who abuse, or those who are dependent on substances (Van den Berg et al., 2003).

It has also been linked to attitudinal and behavioural variables such as help-seeking attitudes, help-seeking behaviour (Beattie et al., 2016), and conservatism (J. M. Pienaar et al., 2006). Several studies have used the FORQ to examine work-related variables such as career commitment (Adejuwon et al., 2015) and work-related consequences, such as compassion satisfaction (Padmanabhanunni, 2020).

\section{Discussion}

The FORQ is a versatile instrument that has been used for different purposes, in different contexts, and in multiple languages among samples across the lifespan, including under-researched and vulnerable groups. It has been applied in cross-sectional, quasi-experimental, qualitative, and triangulation studies as a dependent, independent, and intervening variable.

The FORQ has demonstrated favourable reliability across studies but there were a few exceptions. Laureano et al. (2014), explaining the low reliability found in that study, stated that it is realistic to expect a reliability coefficient below .70 for psychological constructs, while Wissing et al. (2008) attributed the low reliability on the self-appraisal subscale to a more collectivistic as opposed to an individualistic worldview among Black respondents. However, measurement aspects such as factor structure and reliability are characteristics of scores and not of tests; therefore, these characteristics may differ between sets of scores generated by the same instrument.

Several studies confirmed the conceptualization of the FORQ as a total scale and three subscales, through EFA and CFA. One study provided evidence of the FORQ's concurrent validity by demonstrating its consistency with indices of well-being. However, variation in FORQ structure use (as a single scale, as three subscales, or even selected subscales) does not always correspond to the conceptualization of fortitude as an interplay between three sets of appraisals, a conceptualization supported by Hundermark's (2004) qualitative study, which confirmed the interconnectedness of domains.

Furthermore, some studies used the family-appraisal subscale as a measure of support from family. However, both in terms of the original conceptualization, as well as item content, the family-appraisal subscale reflects more than just support from family. Instead, it reflects an evaluative appraisal of the family environment, including level of cohesion, conflict and family values, and thus is not the equivalent of family support. 
Fortitude can play health-sustaining and stress-buffering roles, as has been demonstrated in some studies (Beattie et al., 2016; T. B. Pretorius et al., 2016). The health-sustaining model proposes that high fortitude is associated with high-positive well-being and low-negative well-being. The stress-buffering model indicates that fortitude plays a moderating or mediating role in the relationship between stressors and psychological outcomes.

A promising line of research has been the use of the FORQ in intervention studies. These studies demonstrated that the FORQ measures a construct that is changeable. Therefore, modification of fortigenic appraisals, including through cognitive restructuring interventions, could affect an individual's well-being and adjustment.

The FORQ has displayed sound psychometric properties among varying samples; however, further investigation is needed to evaluate its metric equivalence in different populations. Longitudinal studies with a developmental approach could identify critical psychosocial stages in the development of fortigenic appraisals.

Further quantitative and qualitative study of interactions between the dimensions of fortitude is recommended. For example, a compensatory model might propose that low appraisal in one domain could be compensated for by high appraisal in another.

One of the major limitations of a scoping review methodology is that it does not include a process of quality assessment of primary studies. In other words, the methodology of the identified studies was not evaluated and it is recommended that future research focus on assessing the rigour of the included studies.

\section{Conclusion}

Available evidence has demonstrated that the FORQ has sound psychometric properties. Originally conceptualized as a coping resource, fortitude has demonstrated wide applicability across a range of studies. The scale holds great promise for further research into determinants of well-being, but also as a potential assessment tool for evaluating interventions aimed at modifying appraisals.

\section{Declaration of conflicting interests}

The author(s) declared no potential conflicts of interest with respect to the research, authorship, and/or publication of this article.

\section{Funding}

The author(s) received no financial support for the research, authorship, and/or publication of this article.

\section{ORCID iDs}

Tyrone Brian Pretorius (iD) https://orcid.org/0000-0002-6325-6623

Anita Padmanabhanunni (iD https://orcid.org/0000-0001-7733-7486

\section{References}

Adejuwon, G. A., Aderogba, A., \& Adekeye, O. A. (2015). Health workers' commitment in delta state: Influence of personality and workplace experiences. Mediterranean Journal of Social Sciences, 6(4), 258-258. http://www.richtmann.org/journal/index.php/mjss/article/view/7076

Antonovsky, A. (1979). Health, stress and coping. Jossey-Bass.

Arksey, H., \& O'Malley, L. (2005). Scoping studies: Towards a methodological framework. International Journal of Social Research Methodology, 8(1), 19-32. https://doi.org/10.1080/1364557032000119616 
Barends, M. S. (2004). Overcoming adversity: An investigation of the role of resilience constructs in the relationship between socio-economic and demographic factors and academic coping [Master's dissertation, University of the Western Cape]. http://etd.uwc.ac.za/handle/11394/259

Beattie, B. E., Stewart, D. W., \& Walker, J. R. (2016). A moderator analysis of the relationship between mental health help-seeking attitudes and behaviours among young adults. Canadian Journal of Counselling and Psychotherapy, 50(3). https://cjc-rcc.ucalgary.ca/article/view/61119

Botha, E. M. (2006). Psychological well-being and biological correlates in African women [Doctoral dissertation, North-West University]. https://repository.nwu.ac.za/handle/10394/1219?show=full

Botha, E. M., Wissing, M. P., Ellis, S. M., \& Vorster, H. H. (2007). Psychological well-being and the metabolic syndrome in African and Caucasian women in South Africa. Journal of Psychology in Africa, 17(1-2), 85-92. https://doi.org/10.1080/14330237.2007.10820149

Bouma, R. G. (2000). Psigofortologie by die leergestremde leerder (Psychofortology among the learning disabled learner) [Doctoral dissertation, University of the Free State]. http://hdl.handle.net/11660/7843

Chishima, Y., Mizuno, M., Sugawara, D., \& Miyagawa, Y. (2018). The influence of self-compassion on cognitive appraisals and coping with stressful events. Mindfulness, 9(6), 1907-1915. https://doi.org/10.1007/ s12671-018-0933-0

Cao-Lei, L., Dancause, K. N., Elgbeili, G., Laplante, D. P., Szyf, M., \& King, S. (2016). Pregnant women's cognitive appraisal of a natural disaster affects their children's BMI and central adiposity via DNA methylation: Project ice storm. Early Human Development, 103, 189-192. https://doi.org/10.1016/j.earlhum dev.2016.09.013

Constandius, A. J. (2003). Stress and coping in fathers with severely disabled institutionalised children [Doctoral dissertation, University of the Free State]. https://scholar.ufs.ac.za/handle/11660/4735

De Villiers, M., \& Van den Berg, H. (2012). The implementation and evaluation of a resiliency programme for children. South African Journal of Psychology, 42(1), 93-102. https://doi. org/10.1177/008124631204200110

Edwards, S. D. (2003a). Physical exercise and psychological wellness in health club members: A comparative and longitudinal study. South African Journal for Research in Sport, Physical Education and Recreation, 25(1), 23-33.

Edwards, S. D. (2003b). The structure of a psychological wellness profile. International Journal of Mental Health Promotion, 5(2), 6-11. https://doi.org/10.1080/14623730.2003.9721901

Edwards, S. D. (2006). Physical exercise and psychological well-being. South African Journal of Psychology, 36(2), 357-373. https://doi.org/10.1177/008124630603600209

Geldenhuys, O., \& van Schalkwyk, I. (2019). Investigating the relational well-being of a group of adolescents in a South African high-risk community. Psychology and Behavioural Science, 12(2). https://www. semanticscholar.org/paper/Relational-well-being-of-a-group-of-adolescents-in-Geldenhuys/66da2791d e1955ba1622d140007d79447d03afa8

Gibson, M. M. (1999). Stress-resistance resources: A comparison of hardiness, sense of coherence, potency, egoresilience, fortitude and problem-solving appraisal [Master's dissertation, University of the Western Cape].

Gomes, A. R., Faria, S., \& Vilela, C. (2017). Anxiety and burnout in young athletes: The mediating role of cognitive appraisal. Scandinavian Journal of Medicine \& Science in Sports, 27(12), 2116-2126. https:// doi.org/10.1111/sms.12841

Hameed, I., Khan, M. B., Shahab, A., Hameed, I., \& Qadeer, F. (2016). Science, technology and innovation through entrepreneurship education in the United Arab Emirates (UAE). Sustainability, 8(12), 1280. https://doi.org/10.3390/su8121280

Hamid, S., \& Singaram, V. S. (2016). Motivated strategies for learning and their association with academic performance of a diverse group of 1st-year medical students. African Journal of Health Professions Education, 8(1), 104-107. https://www.ajol.info/index.php/ajhpe/article/view/135516

Helmand, A. (2001). Die verband tussen psigofortigene faktore, toekomstydperspektief en lewenstevredenheid by persone na traumatiese hoofbeserings (The relationship between psychofortological factors, future perspective and life satisfaction amongst persons with traumatic head injury) [Doctoral dissertation, University of the Free State]. https://scholar.ufs.ac.za/handle/11660/8057 
Heyns, P. M., Venter, J. H., Esterhuyse, K. G., Bam, R. H., \& Odendaal, D. C. (2003). Nurses caring for patients with Alzheimer's disease: Their strengths and risk of burnout. South African Journal of Psychology, 33(2), 80-85. https://doi.org/10.1177/008124630303300202

Hill, A. (2003). Die verband tussen psigologiese welstand en kognitiewe buigsaamheid by adolessente (The relationship between psychological wellbeing and cognitive flexibility amongst adolescents) [Doctoral dissertation, University of the Free State]. http://hdl.handle.net/11660/5477

Hundermark, J. (2004). Exploring dimensions of fortitude: A qualitative investigation of sources of resilience among university students with a physical disability [Master's dissertation, University of the Western Cape].

Julius, M. N. (1999). The influence of gender and fortitude on the types of problems that students present with at the institute for counselling at the University of the Western Cape [Master's dissertation, University of the Western Cape].

Khumalo, I. P., Temane, Q. M., \& Wissing, M. P. (2011). Well-being in the Batswana cultural context: Constructs and measures. Journal of Psychology in Africa, 21(2), 277-285. https://doi.org/10.1080/143 30237.2011.10820456

Khumalo, I. P., Wissing, M. P., \& Temane, Q. M. (2008). Exploring the validity of the Values-In-Action Inventory of Strengths (VIA-IS) in an African context. Journal of Psychology in Africa, 18(1), 133-142. https://doi.org/10.1080/14330237.2008.10820180

Koen, V. (2009). The parent-adolescent relationship and the emotional well-being of adolescents [Master's dissertation, North-West University]. http://hdl.handle.net/10394/4825

Kok, I. (2013). Psychological well-being, race and school setting: A comparative study among South African teachers in the SABPA study [Master's dissertation, North West University]. http://hdl.handle. net/10394/11178

Laureano, C., Grobbelaar, H. W., \& Nienaber, A. W. (2014). Facilitating the coping self-efficacy and psychological well-being of student rugby players. South African Journal of Psychology, 44(4), 483-497. https://doi.org/10.1177\%2F0081246314541635

Lazarus, R. S., \& Folkman, S. (1984). Stress, appraisal, and coping. Springer.

Levac, D., Colquhoun, H., \& O'Brien, K. K. (2010). Scoping studies: Advancing the methodology. Implementation Science, 5(1), 69. https://doi.org/10.1186/1748-5908-5-69

Microsoft Corporation. (2016). Microsoft excel. https://office.microsoft.com/excel

Nel, L. (2003). Clarifying the interpersonal component of psychological well-being [Master's dissertation, North-West University]. http://hdl.handle.net/10394/181

Padmanabhanunni, A. (2020). Caring does not always cost: The role of fortitude in the association between personal trauma exposure and professional quality of life among lay trauma counsellors. Traumatology. Advance online publication. https://doi.org/10.1037/trm0000262

Peters, E. (2005). Neuropsychological executive functioning and psychosocial well-being [Doctoral dissertation, North-West University]. http://hdl.handle.net/10394/865

Pienaar, I. (2002). Die verband tussen hoop en psigologiese welstand by adolessente (The relationship between hope and psychological wellbeing amongst adolescents) [Doctoral dissertation, University of the Free State]. http://hdl.handle.net/11660/8061

Pienaar, J. M., Beukes, R. B., \& Esterhuyse, K. G. (2006). The relationship between conservatism and psychological well-being in adolescents. South African Journal of Psychology, 36(2), 391-406. https://doi. org/10.1177\%2F008124630603600211

Potgieter, F. (2004). The experience of wellness in early adulthood: A multicultural perspective [Master's dissertation, University of the Free State]. http://hdl.handle.net/11660/6343

Potgieter, J. C. (2002). Tydsperspektief as potensiële psigofortigene konstruk by die rouproses van versorgers van Alzeimer-pasiënte (Time perspective as potential psychofortigenic construct in the grieving process of caregivers of Alzheimer patients) [Doctoral dissertation, University of the Free State]. http://hdl. handle.net/11660/5361

Potgieter, J. C., \& Heyns, P. M. (2006). Caring for a spouse with Alzheimer's disease: Stressors and strengths. South African Journal of Psychology, 36(3), 547-563. https://doi.org/10.1177\%2F008124630603600307

Pretorius, C., Walker, S., \& Heyns, P. M. (2009). Sense of coherence amongst male caregivers in dementia: A South African perspective. Dementia, 8(1), 79-94. https://doi.org/10.1177\%2F1471301208099046 
Pretorius, T. B. (1998). Fortitude as stress-resistance: Development and validation of the Fortitude Questionnaire (FORQ). University of the Western Cape. https://www.uwc.ac.za/RectorsOffice/Pages/ inferential_data_files.aspx

Pretorius, T. B., Padmanabhanunni, A., \& Campbell, J. (2016). The role of fortitude in relation to exposure to violence among adolescents living in lower socio-economic areas in South Africa. Journal of Child \& Adolescent Mental Health, 28(2), 153-162. https://doi.org/10.2989/17280583.2016.1200587

Rahim, M. Z. (2007). Investigating the relationship between fortitude and academic achievement in students from historically disadvantaged backgrounds [Doctoral dissertation, University of the Western Cape]. http://etd.uwc.ac.za/handle/11394/2762

Roothman, B., Kirsten, D. K., \& Wissing, M. P. (2003). Gender differences in aspects of psychological well-being. South African Journal of Psychology, 33(4), 212-218. https://doi.org/10.1177 \%2F008124630303300403

Talbot, B. D. (2012). The prediction of psychological well-being in children and adolescents with chronic, life threatening illnesses [Doctoral dissertation, University of the Free State]. http://hdl.handle. net/11660/1545

Taylor, H. W. (2002). Die verband tussen fortigene faktore en psigologiese welstand by SAPD-lede in hoërisiko-eenhede (The relationship between fortigenic factors and psychological wellbeing amongst police members in high risk units) [Master's dissertation, University of the Free State]. http://hdl.handle. net $/ 11660 / 8378$

Van den Berg, H. S., Pretorius, C., \& Louw, D. A. (2003). Psychosocial predictors of substance abuse among adolescents. Acta Criminologica: Southern African Journal of Criminology, 16(4), 1-11. https://www. ingentaconnect.com/content/sabinet/crim/2003/00000016/00000004/art00002

Van Schalkwyk, I., \& Wissing, M. P. (2013). Evaluation of a programme to enhance flourishing in adolescents. In M. Wessing (Ed.), Well-being research in South Africa (pp. 581-605). Springer.

Van Wyk, M. M. (2010). Validation of a coping self-efficacy scale in an African context [Master's dissertation, North-West University]. http://hdl.handle.net/10394/4883

Venter, S. (2004). Die verband tussen psigososiale faktore en uitbranding by entrepreneurs (The relationship between psychosocial factors and burnout amongst entrepreneurs) [Master's dissertation, University of the Free State]. http://hdl.handle.net/11660/8306

Vermaas, E. (2010). Social support as a moderator between stress and psychological well-being [Master's dissertation, North-West University]. http://hdl.handle.net/10394/6983

Viljoen, G. (2003). Wysheid as psigofortigene konstruk in die versorging van pasiënte met Alzheimer se siekte (Wisdom as psychofortigenic construct in caring for patients with Alzheimer's disease) [Master's dissertation, University of the Free State]. https://scholar.ufs.ac.za/handle/11660/7621

Wiid, C. (2019). The role of fortitude in psychological outcome in relation to traumatic events experienced by young adults [Master's dissertation]. University of the Western Cape.

Wissing, J. A. B., Wissing, M. P., Du Toit, M. M. Q., \& Michael Temane, Q. M. (2008). Psychometric properties of various scales measuring psychological well-being in a South African context: The FORT 1 Project. Journal of Psychology in Africa, 18(4), 511-520. https://doi.org/10.1080/14330237.2008.10820230

Wissing, M. P., \& Temane, Q. M. (2008). The structure of psychological well-being in cultural context: Towards a hierarchical model of psychological health. Journal of Psychology in Africa, 18(1), 45-55. https://doi.org/10.1080/14330237.2008.10820170

Wissing, M. P., \& Temane, Q. M. (2013). The prevalence of levels of wellbeing revisited in an African context. In C. L. M. Keyes (Ed.), Mental Well-Being: International contributions to the study of positive mental health (Chapter 4, pp. 71-90). Springer.

Wissing, M. P., Temane, Q. M., Khumalo, I. P., Kruger, A., \& Vorster, H. H. (2013). Psychosocial health: Disparities between urban and rural communities. In Well-being research in South Africa (pp. 415-438). Springer.

Yeung, N. C., Lu, Q., Wong, C. C., \& Huynh, H. C. (2016). The roles of needs satisfaction, cognitive appraisals, and coping strategies in promoting posttraumatic growth: A stress and coping perspective. Psychological Trauma: Theory, Research, Practice, and Policy, 8(3), 284-292. https://psycnet.apa.org/doi/10.1037/tra0000091

Yuwanto, L., \& Atmadji, G. (2017). Pengembangan Fortitude Questionnaire Versi Indonesia. Jurnal Ilmiah Psikologi MIND SET, 8(1), 31-36. 